Egypt. Acad. J. Biolog. Sci., 13(1):123-133 (2020)

Egyptian Academic Journal of Biological Sciences

A. Entomology

ISSN 1687- 8809

http://eajbsa.journals.ekb.eg/

\title{
Enhancing the Efficacy of Certain Spray-Dried Baculovirus (AgipMNPV) against Cutworm, Agrotis ipsilon Hufnagel (Lepidoptera: Noctuidae)
}

\section{Atef M. M. Sayed ${ }^{1}$, Robert W. Behle ${ }^{2}$, and Ghada N. El-Masry ${ }^{1}$}

1- Plant Protection Research Institute, Agricultural Research Center, Dokki, Egypt.

2- United States Department of Agriculture, Agricultural Research Service, National

Center for Agricultural Research, Crop Bioprotection Research Unit, Peoria, Illinois, USA.

Email: atef.mahmoud1@gmail.com

\section{ARTICLE INFO Article History \\ Received: $16 / 2 / 2020$ \\ Accepted:9/3/2020}

\section{Keywords:}

Spray-dried

formulations,

Baculovirus

(AgipMNPV),

Agrotis ipsilon,

\section{ABSTRACT}

The insecticidal efficacy of various baculovirus formulations against the cutworm Agrotis ipsilon was determined. The treatments consisted of molasses from suagrcane mixing with each of wheat germ, biochar, talc, chitosan, silica gel, pyrolysis bio-oilaqueous phase, pyrolysis bio-oilorganic phase, calcium carbonate, cornflour, calcium cassinate, aluminium potasium sulphate, Diatomaceous earth, dextrin, lignin PC 1307, soy screen, blankphor, skim milk powder, potassium cassinate, magnsium chloride, date molasses and pregelatinized starch. All applied in spray-dried at $2.2 \times 10^{9}$ occlusion body $(\mathrm{OB}) \mathrm{mL}^{-1}$. The bioassay of each spray-dried formulation using the droplet feeding method by the blue solution containing $2 \%$ sugar and $0.1 \%$ blue dye. The resulting suspensions should all contain $0.377 \times 10^{6} \mathrm{OB} \mathrm{mL}^{-1}$, represent the $\mathrm{LD}_{70}$ for the unformulated virus. Exposure newly hatched larvae of cutworms and transfer to individual diet cups for each treatment and incubated at $28^{\circ} \mathrm{C}$ in dark incubator for 7 days. The obtained results revealed that satisfactory control of the pest of $100 \%$ larval mortality compared to untreated control was achieved with the formulations containing molasses mixing with talc, silica gel, calcium carbonate, cornflour, calcium cassinate, diatomaceous earch, soy screen, and dextrin. However, the formulations containing chitosan, pyrolysis bio-oilaqueous phase and pyrolysis biooilorganic phase gave the lowest mortalities as 12.2, 11.1 and 6.7\%, respectively. These findings is an attempt to provides an interesting alternative developed biopesticide formulations made with natural ingredients that could improve the efficacy and persistence of virus-based biopesticides.

\section{INTRODUCTION}

Baculoviruses (family: Baculoviridae; genus: Nucleopolyhedroviruses) are a highly diverse group of circular double-stranded DNA genome viruses and present a seemingly good alternative to broad-spectrum insecticides attributed to their efficacy, specificity, and safety to humans and other non-target organisms (Ikeda et al., 2015; and Herniou et al., 2011). Due to their high virulence and narrow host range, baculoviruses have been developed as environmentally sound microbial pesticides for pest management in agriculture, 
horticulture and forestry settings around the world (Kabaluk et al., 2010; Szewczyk et al., 2009; and Erlandson, 2008).

Two different types of virions were formed during the infection cycle of the baculoviruses. Virions that received their membrane from the plasma membrane of the host cell the cell are called budded viruses (BV), it contains only a single nucleocapsid. Occlusion Derived Virions (ODV) are assembled within the host cell. It embedded within a crystalline protein matrix that forms occlusion bodies $(\mathrm{OB})$. Furthermore, baculoviruses are divided into two morphological groups according to their OB morphology. The OBs of granuloviruses (GV) (genus Betabaculovirus) contain only one virion and are smaller than those of the nucleopolyhedroviruses (NPV) (genera Alpha-, Gamma- and Deltabaculovirus), which contain numerous ODVs (Herniou et al., 2011). The OB is the infectious stage of the virus and is important in spreading the virus between hosts (Cory and Myers, 2003).

The cutworm, Agrotis ipsilon (Hufnagel) (Lepidoptera: Noctuiidae) is a seriously devastating agricultural insect pest of field crops, vegetables, ornamental plants, golf course and sports fields worldwide. Cutworms spend most of their life cycle underground or close to the soil surface where feed on seedlings, stems, and other parts of plants. A. ipsilon causes severe crop damages in infested plant fields varies from $20-80 \%$ due to its various host range, hidden lifestyle, feeding behavior, prolonged egg-laying, and its ability for long-distance migration. More than $80 \%$ of the losses occur after reaching the fourth instar of larvae, which cuts several plants overnight (Binning et al., 2015, Liu et al., 2015). It is difficult to detect, especially late larval stages that stay within the soil. So, will be complicated their control by spray applications of insecticides and remains inadequate for the control of this pest because of its larval hiding behavior during the daylight hours and the resistance to most of the chemicals (Brosi \&Potteri, 2010). Therefore, the negative impact of the chemicals has led researchers to search for new control strategies.

Hence, alternative more consumer-friendly and environmentally safe biocontrol agents are needed for controlling this pest.

The baculovirus, Agrotis ipsilon multicapsid nucleopolyhedrovirus (AgipMNPV) was isolated and characterized successfully from larvae of the cutworm. Recently, it used as a potential alternative microbial agent for suppression of A. ipsilon (Harrison, 2009; Prater et al., 2006; Bourner and Cory, 2004; and Behle, 2017).

Enhancing the efficacy of baculovirus by adding some ingredients which increased infection and improved pest control. The aim of the formulation is to combine the advantageous effects of formulation ingredients without compromising on cost, efficacy, and protection from adverse environmental factors (Behle et al., 2006). In addition to improving the speed of kill, efficacy, host range, and persistence applied research on the formulation of $\mathrm{BV}$ remains one of the most important routes to BV product improvement (Behle and Birthisel, 2014). Adjuvant may need to be incorporated_to inhibit microbial contamination as well as protect the baculovirus from adverse environmental factors such as temperature, leaf surface exudates, sunlight, wind, and rain, thereby improving their persistence, helping to maintain their insecticidal activity, enhance storage stability and maximize application efficiency (Behle et al., 2011; Lasa et al., 2009). Additives that enhance the active ingredient such as flour, oil, and sugar often act as phagostimulants and have other enhancing properties such as facilitating adhesion of the virus to plants. These can be used as carriers or encapsulating agents to spray-dry the active ingredients (Tamez-Guerra et al., 2002)

Spray-drying has been used successfully to produce powders of nucleopolyhedroviruses, and this enables them to withstand spray-drying conditions (Arhurs and Lacey, 2004). This process has the advantage that it may kill contaminating microorganisms in the product (Jones and Burges, 1997). Dry formulations are easier to 
handle and store than liquid formulations due to their reduced weight and package size (Seaman, 1990).

Efforts have been ongoing to develop strains of baculoviruses with greater potency or other attributes to decrease the cost of their use through a lower cost of production or application. This research reported an attempt aimed to determine the bioinsecticidal activity of various spray-dried formulations with the baculovirus AgipMNPV for managing Agrotis ipsilon.

\section{MATERIALS AND METHODS}

\section{Rearing of Experimental Insect:}

A population of the cutworm Agrotis ipsilon has been provided by Dr. Mortada (Cutworm Research Department, Plant protection Research, Dokki, Egypt) and maintained on Southland cutworm commercial insect diet (Southland Products, Inc., Lake Village, AR) at Plant Protection Laboratory, Ismailia Agricultural Research Station, Ismailia, Egypt, where it was established for several generations as described by Behle 2017.

Adult moths were kept for two weeks in groups of about 20 individuals in transparent plastic cylinders $(20 \mathrm{~cm}$ diameter, $25 \mathrm{~cm}$ height) that were faced inside with rough-surfaced paper tissues. Insect eggs were collected three times a week by replacing the paper tissues; they were incubated at $25^{\circ} \mathrm{C}$ for several days until hatching. Thirty neonates were transferred onto an artificial diet of soy-wheat germ diet (Frontier Scientific Service-USA) in individual cups to fill a plastic tray of 30 cups. Each cup containing $3 \mathrm{~mL}$ artificial diet. Larvae were kept in an incubator at $25^{\circ} \mathrm{C}$ with a $16 / 8 \mathrm{~h}$ light/dark photoperiod until they reached the pupal stage. Pupae were collected and incubated at $25^{\circ} \mathrm{C}$ until the imagoes hatched.

\section{Baculovirus Preparation:}

Agrotis ipsilon multicapsid nucleopolyhedrovirus (AgipMNPV) stock was provided by Dr. Robert Behle (USDA-ARS-National Center for Agricultural Utilization Research, Crop Bioprotection Research Unit, Peoria, IL. USA). This stock was produced by a single amplification passage through A. ipsilon larvae and was purified by a series of centrifugation and washing steps. AgipMNPV polyhedral occlusion bodies (OBs) were enumerated by a Neubauer bright-line hemocytometer (Fisher, Pittsburg, PA) with a phase-contrast microscope.

For producing a fresh virus, five larvae were transferred onto chunks of Southland diet per cup to fill a tray of 30 cups and incubated for 7 days at $27^{\circ} \mathrm{C}$. A total of 30 trays of Southland diet, by dispensing a thin layer of diet in each cup. Cups were prepared and treated with $100 \mu \mathrm{L}$ virus suspension per cup at a concentration of $10^{6} \mathrm{OB} \mathrm{mL}^{-1}$. When larvae reached 7 days incubation, only one larva was transferred into each treated cup and covered with a lid. Then, the treated larvae were incubated for 7 days at $28^{\circ} \mathrm{C}$. Dead larvae were harvested for OB purification. Polyhedra extracted and purification as described previously by Behle, 2017; and Boughton et al., 2001. Sodium azide was added to polyhedral preparations to a final concentration of $0.02 \%$ to prevent bacterial growth, and virus stocks were stored at $4^{\circ} \mathrm{C}$. The cadavers were thoroughly homogenized in $0.5 \%$ sodium dodecyl sulfate (SDS) using homogenizer. The resulting suspension was filtered through three layers of gauze that were washed with additional volumes of $0.5 \%$ SDS. The OBs were pelleted at centrifuge of $750 \mathrm{~g}$ for $10 \mathrm{~min}$ and then washed three times by re-suspending the pellet twice in $0.1 \% \mathrm{SDS}$ and once in $0.5 \mathrm{M} \mathrm{NaCl}$. The OBs were then centrifuged again at $750 \mathrm{~g}$ for 10 min and resuspended in an appropriate volume of deionized water $(\mathrm{dH} 2 \mathrm{O})$. For $\mathrm{OB}$ purification, the homogenate was centrifuged at $5000 \mathrm{~g}$ for $10 \mathrm{~min}$ and the pellet was resuspended in $0.5 \%$ SDS. The OB suspension was pelleted, then washed in $0.5 \mathrm{M} \mathrm{NaCl}$, 
pelleted again and finally re-suspended in a smaller volume of $\mathrm{dH} 2 \mathrm{O}$. All OB purification stock were stored at $-20^{\circ} \mathrm{C}$ until used.

\section{Formulation Preparation:}

Twenty-three ingredients were made with the baculovirus AgipMNPV. Materials for each formulation as shown in Tables $1 \& 2$ were mixed in water, then the mixture was spraydried. Molasses-based spray-dried formulations were selected and prepared to determine to screen the optimal ingredients for insecticidal activity of baculovirus by a dosage-response droplet-feeding assay.

Twenty-three spray-dried formulations ingredients were made with molasse (Kroger Stores Inc., Bentonville AR, USA) included as follow: Calcium carbonate; Magnsium chloride; Potassium caseinate; Aluminium potassium sulfate dodecahydrate $\left(\mathrm{AlKO}_{8} \mathrm{~S}_{2} 12\right.$ $\left.\mathrm{H}_{2} \mathrm{O}\right)$; Pregelatinized starch; corn flour; silica gel $\left(\mathrm{SiO}_{2}\right.$, high-purity grade, pore size $60 \AA$, 200 mesh particle size); Chitosan (Crab shell, $\geq 85 \%$ deacetylated), crab-shell chitosan solution $(1 \%, \mathrm{wt} / \mathrm{vol})$ of chitosan was prepared by dissolving $10 \mathrm{~g}$ of chitosan in $1 \%$ aqueous solution of the acetic acids under continuous stirring at $60^{\circ} \mathrm{C}$ for overnight to improve the solubility of chitosan and then followed by centrifugation at $5000 \mathrm{rpm}, 20^{\circ} \mathrm{C}$ for $25 \mathrm{~min}$ to separated not dissolved chitosan particles, the $\mathrm{pH}$ values of the chitosan solutions was adjusted to 4.0 and by adding $0.1 \mathrm{M}$ hudroxide sodium for $\mathrm{pH}$ adjusted to 6.8. The previous compounds were purchased from Sigma-Aldrich (Chemical Co., St Louis, Mo, USA).

The other compounds were wheat germ (Great Value, Walmart Stores Inc., Bentonville AR, USA); Non-fat instant dry milk (skim milk powder); Talc (Hydrous magnesium silicate, Fisher Scientific, 1 Reagent Lane, Fair Lawn, NJ); Diatomaceous earth (HYFLO, Celite Corp., Lompoc, CA, USA); Soy screen (10\%, composite, 0.486:100 soy screen: starch ratio, ca:32.7 soy, NCAUR sample 19238-330 powder);

Biochar (Biochar Options LCC, Hartland WI, USA), the procedure of preparing the biochar sample suspensions was identical to the described by Wang et al., 2013, the pHs of the biochar suspensions were adjusted to 6.8 and other suspension was buffered by adding $\mathrm{NaHCO}_{3} 16.8 \mathrm{~g}$ to $\mathrm{pH}$ adjusted to 6.8.; The used bio-oils (aquous and organic phases) was obtained from Robert. A. Moreau and Charles A. Mullen (Sustainable Biofuels and CoProducts Research Unit, Eastern Regional Research Center, 600 East Mermaid Lane Wyndmoor PA 19038);

Lignin (PC-1307, Westvaco, Charleston Heights, SC) which dissolved in water at $10 \% \mathrm{w} / \mathrm{w}$. Then, virus stock was added to the lignin solution $(50 \mathrm{~mL})$ followed by adding slowly calcium chloride dihydrate $\left(1 \mathrm{~g} \mathrm{CaCl}_{2} 2 \mathrm{H}_{2} \mathrm{O}\right.$ diluted in $60 \mathrm{ml}$ water $)$ while stirring vigorously in a blender to creating the dryer feedstock, after the lignin dissolved, the $\mathrm{pH}$ was adjusted to 9.41 ;

The optical brightener blankophor (Bayer, Houston, TX), $4 \mathrm{~g}$ in $50 \mathrm{~mL}$ followed by added slowly solution of $1 \mathrm{~g} \mathrm{CaCl}_{2} 2 \mathrm{H}_{2} \mathrm{O}$ in $30 \mathrm{~mL}$ to creating the dryer feedstock.

For all the previous prepared formulations, the $\mathrm{pH}$ was adjusted for each. The virus concentration per gram of solids is a calculated value based on the count of the technical virus and the amounts of the added ingredients as shown in Tables $1 \& 2$. 
Table 1. List of ingredients used for spray-dried formulations of AgipMNPV tested against Agrotis ipsilon

\begin{tabular}{|c|c|c|c|c|c|c|c|c|c|c|c|}
\hline Ingredients Formulations & $\begin{array}{l}\text { Wheat } \\
\text { germ }\end{array}$ & Talc & Silica & $\begin{array}{l}\text { Calcium } \\
\text { carbonate }\end{array}$ & $\begin{array}{l}\text { Corn } \\
\text { flour }\end{array}$ & $\begin{array}{l}\text { Calcium } \\
\text { cassinate }\end{array}$ & $\begin{array}{l}\text { Aluminium } \\
\text { Potassium } \\
\text { sulphate }\end{array}$ & $\begin{array}{c}\text { Magnsium } \\
\text { Chloride }\end{array}$ & $\underset{1307}{\operatorname{Lignin} P C}$ & Blankphore & $\begin{array}{c}\text { Date } \\
\text { molasse }\end{array}$ \\
\hline Molasse (sugarcane) & $1.25 \mathrm{~g}$ & $1.25 \mathrm{~g}$ & $1.25 \mathrm{~g}$ & $1.25 \mathrm{~g}$ & $1.25 \mathrm{~g}$ & $1.25 \mathrm{~g}$ & $1.25 \mathrm{~g}$ & $1.25 \mathrm{~g}$ & $1.25 \mathrm{~g}$ & $1.25 \mathrm{~g}$ & $125 \mathrm{~g}$ \\
\hline Wheat germ & $5 \mathrm{~g}$ & & & & & & & $5 \mathrm{~g}$ & & & \\
\hline Talc & & $5 \mathrm{~g}$ & & & & & & & & & \\
\hline Silica gel & & & $5 \mathrm{~g}$ & & & & & & & & \\
\hline Calcium carbonate & & & & $5 \mathrm{~g}$ & & & & & & & \\
\hline Corn flour & & & & & $5 \mathrm{~g}$ & & & & & & \\
\hline Calcium cassinate & & & & & & $5 \mathrm{~g}$ & & & & & \\
\hline $\begin{array}{l}\text { Aluminium Potassium } \\
\text { sulphate }\end{array}$ & & & & & & & $5 \mathrm{~g}$ & & & & \\
\hline Magnsium Chloride & & & & & & & & 0.25 & & & \\
\hline Lignin PC 1307 & & & & & & & & & $\begin{array}{c}50 \mathrm{ml} \text { of } 10 \% \\
\text { solution }\end{array}$ & & \\
\hline Blankphor & & & & & & & & & & $\begin{array}{c}4 \mathrm{~g} \text { in } 50 \mathrm{~mL} \\
\text { (added } \\
\text { slowly } 1 \mathrm{~g} \\
\mathrm{CaCl}_{2} \text { in } 30 \\
\mathrm{ml}\end{array}$ & \\
\hline Date molasse & & & & & & & & & & & $5 \mathrm{~g}$ \\
\hline Total weight & $6.25 \mathrm{~g}$ & $6.25 \mathrm{~g}$ & $6.25 \mathrm{~g}$ & $6.25 \mathrm{~g}$ & $6.25 \mathrm{~g}$ & $6.25 \mathrm{~g}$ & $6.25 \mathrm{~g}$ & $6.25 \mathrm{~g}$ & $6.25 \mathrm{~g}$ & $6.50 \mathrm{~g}$ & $6.25 \mathrm{~g}$ \\
\hline $\begin{array}{l}\text { Unformulated virus } \\
\text { (a) } 1.05 \times 10^{9} \mathrm{OB} / \mathrm{mL}\end{array}$ & & & & & & & $3 \mathrm{~mL}$ & & & & \\
\hline Final volume at $5 \%$ solids & & & & & & & $25 \mathrm{~mL}$ & & & & \\
\hline Expected virus load OB/g & & & & & & 2.2 & $109 \mathrm{OB} / \mathrm{g}$ & & & & \\
\hline pH & 7.37 & 7.02 & 6.06 & 8.47 & 5.31 & 6.1 & 3.18 & 9.41 & 10.09 & 7.53 & 6.41 \\
\hline
\end{tabular}

Table 2. List of ingredients used for spray-dried formulation of AgipMNPV tested against Agrotis ipsilon.

\begin{tabular}{|c|c|c|c|c|c|c|c|c|c|c|c|c|}
\hline $\begin{array}{ll}\text { Ingredients } & \text { Formulations } \\
\end{array}$ & Biochar & Chitosan & $\begin{array}{l}\text { Bio-oil } \\
\text { (organic } \\
\text { phase) }\end{array}$ & $\begin{array}{l}\text { Bio-oil } \\
\text { (aqueous } \\
\text { phase) }\end{array}$ & \begin{tabular}{|c|} 
Pre- \\
gelatinized \\
starch
\end{tabular} & DE & $\begin{array}{c}\text { Soy } \\
\text { Screen }\end{array}$ & Dextrin & SKM & $\begin{array}{l}\text { Potassium } \\
\text { cassinate }\end{array}$ & Chitosan & Biochar \\
\hline Molasse (sugarcane) & $1.25 \mathrm{~g}$ & $1.25 \mathrm{~g}$ & $1.25 \mathrm{~g}$ & $1.25 \mathrm{~g}$ & $1.25 \mathrm{~g}$ & $1.25 \mathrm{~g}$ & $1.25 \mathrm{~g}$ & $1.25 \mathrm{~g}$ & $1.25 \mathrm{~g}$ & $1.25 \mathrm{~g}$ & $1.25 \mathrm{~g}$ & $1.25 \mathrm{~g}$ \\
\hline Biochar $(125 \mathrm{~mL})+200 \mathrm{~mL} \mathrm{NaHCO}{ }_{3}$ & $21 \mathrm{~g}$ & & & & & & & & & & & \\
\hline Chitosan $+50 \mathrm{~mL} \mathrm{NaOH}(0.1 \mathrm{M})$ & & $1.75 \mathrm{~g}$ & & & & & & & & & & \\
\hline Bio-oil (pyrolysis organic phase) & & & $5 \mathrm{~g}$ & & & & & & & & & \\
\hline Bio-oil (pyrolysis aqueous phase) & & & & $5 \mathrm{~g}$ & & & & & & & & \\
\hline Pregelatinized starch & & & & & $5 \mathrm{~g}$ & & & & & & & \\
\hline Diatomaceous earth (DE) & & & & & & $5 \mathrm{~g}$ & & & & & & \\
\hline Soy Screen & & & & & & & $5 \mathrm{~g}$ & & & & & \\
\hline Dextrin & & & & & & & & $5 \mathrm{~g}$ & & & & \\
\hline Skim milk powder (SKM) & & & & & & & & & $5 \mathrm{~g}$ & & & \\
\hline Potassium cassinate & & & & & & & & & & $5 \mathrm{~g}$ & & \\
\hline Chitosan & & & & & & & & & & & $1 \%$ & \\
\hline $\begin{array}{l}\text { Biochar }+20 \mathrm{~mL} \text { potassium phatlate } \\
0.05 \mathrm{M} \text {, buffer } 4.0\end{array}$ & & & & & & & & & & & & $5 \mathrm{~g}$ \\
\hline Expected total weight & $22.25 \mathrm{~g}$ & $3.0 \mathrm{~g}$ & $6.25 \mathrm{~g}$ & $6.25 \mathrm{~g}$ & $6.25 \mathrm{~g}$ & $6.25 \mathrm{~g}$ & $6.25 \mathrm{~g}$ & $6.25 \mathrm{~g}$ & $6.25 \mathrm{~g}$ & $6.25 \mathrm{~g}$ & $2.25 \mathrm{~g}$ & $6.25 \mathrm{~g}$ \\
\hline $\begin{array}{l}\text { Unformulated virus } \\
\text { (a) } 1.05 \times 10^{9} \mathrm{Ob} / \mathrm{ml}\end{array}$ & \multicolumn{12}{|c|}{$4.3 \mathrm{~mL}$} \\
\hline Final volume at $5 \%$ solids & \multirow{2}{*}{\multicolumn{12}{|c|}{$\frac{125 \mathrm{~mL}}{2.2 \times 10^{9} \mathrm{OB} / \mathrm{g}}$}} \\
\hline Expected virus load OB/g & & & & & & & & & & & & \\
\hline pH & 8.76 & 4.00 & 3.51 & 4.75 & 6.05 & 8.04 & 5.86 & 6.03 & 7.17 & 6.8 & 6.22 & 6.41 \\
\hline
\end{tabular}

\section{Spray Drying Formulations:}

Each spray-dried molasse formulation was made to contain $2.2 \_$x $10^{9} \mathrm{OB} \mathrm{mL}^{-1}$. Evaluating the spray drying of AgipMNPV formulations in the final product based on the OB count provided with the virus stock and the weight of ingredients added to the formulation. The first step in mixing the dryer feedstock for the prepared twenty-three ingredients was to determine the amount of product to be able to calculate the amount of water $(125 \mathrm{~mL})$ required to provide a final spray-dryer feedstock consisting of $/ 5 \%(\mathrm{w} / \mathrm{v})$ solids.

All spray-dried formulations of the feedstock suspensions $(125 \mathrm{~mL})$ with a concentration of $2.2 \times / 10^{9} \mathrm{OB} \mathrm{mL} \mathrm{mL}^{-1}$ were dried in a Niro atomizer portable spray dryer (Niro, Columbia, MD, USA). Spray-drying conditions were inlet temperature of $130-135^{\circ} \mathrm{C}$, the outlet temperature of $60-70^{\circ} \mathrm{C}, 4.5$ heat setting, air pressure of $5.6 \mathrm{~kg} / \mathrm{cm} 2,5 \%$ solids (w/v) feedstock concentration and $20 \mathrm{~mL} \mathrm{~min}^{-1}$ feed rate. Each suspension was continually agitated using a magnetic stirrer during spray-drying to ensure that the active ingredient 
remained evenly suspended. The percentage of powder recovery was calculated based on the amounts of dry ingredients used in the feedstock. The water activity $\left(a_{\mathrm{w}}\right)$ of these suspensions was measured using the AquaLab series 4TEV (Decagon Devices, Inc., Pullman, WA, USA) equilibrated at $25^{\circ} \mathrm{C}$. The resulting dried powder was expected to contain $2.2 \mathrm{x} / 10^{9} \mathrm{OBs} \mathrm{g}^{-1}$. Fresh preparations were made within 2 weeks of use.

\section{Bioassay:}

The activity of spray-dried formulations prepared with virus cutworm (AgipMNPV) at $2.2 \times 10^{9}$ occlusion bodies (OB) $\mathrm{mL}^{-1}$ was performed using a modified droplet feeding method described by Hughes et al., 1986. Each spray-dried formulation ingredient sample was mixed into $10 \mathrm{~mL}$ of a feeding blue solution containing $2 \%(\mathrm{w} / \mathrm{w})$ sucrose, and $0.1 \%$ blue dye (w/w) FD\&C Blue 1 (Noveon Hilton Davis, Cincinnati, OH). Then, sonicate at 40\% for 5 seconds by probe sonicator. The resulting suspensions should contain $0.377 \times 10^{6} \mathrm{OB}$ $\mathrm{mL}^{-1}$ which represents the lethal dose (LD70) for the unformulated virus that based on the results was obtained by Behle, 2017.

After mixing, about 60 small drops from each sample were placed in individual plastic 50-mm Petri dishes. Five Petri dishes per treatment were employed. 15 neonate $A$. ipsilon were placed in each dish to feed on the drops and Petri dishes were capped to reduce evaporation of the droplets. After feeding for about $5 \mathrm{~min}$, six larvae with blue stained intestines from each dish were transferred to individual cups containing $3 \mathrm{~mL}$ artificial diet to fill a tray of 30 cups representing a replicate. Three replicates for each treatment and incubated for 7 days at $28^{\circ} \mathrm{C}$ in a dark Conviron I24 L incubator (Controlled Environments, Inc., Asheville, NC). After incubation, the numbers of live and virus-killed larvae were counted to calculate the mortality percentage for each treatment. Dead larvae that were not symptomatic for virus infection were omitted from statistical analysis.

\section{Data Analysis:}

All experiments were conducted using a completely randomized design. All experiments were repeated three times on different dates using different insect cohorts. Viral formulations made with different ingredients were subjected to analysis of variance (ANOVA) and treatment means were separated using Tukey's statistic test at $P 0.05$. All analyses were performed by using software Biostat (2009).

\section{RESULTS AND DISCUSSION}

Spray-dried formulations of AgipMNPV made with molasse had greatly significant different levels of activity effect $\left(F_{22,206}=217.17, P<0.0001\right)$ based on the ingredients added to the formulation. Statistical analysis of the results indicated that satisfactory control of the pest of $100 \%$ larval mortality compared to untreated control was significantly achieved with the formulations containing molasse mixing with talc, silica, calcium carbonate, cornflour, calcium cassinate, diatomaceous earch, soy screen, and dextrin. Also, wheat germ, date molasse, skim milk powder and potassium cassinate gave 92.08, 91.25, 94.18 and 93.75\%, respectively as shown in Table 3 and Figure 1.

Mortality of larvae exposed to formulation made with biochar (with buffer at 4.0), magnsium chloride, aluminium potasium sulphate, blankphor and pregelatinized starch gave 91.53, 90.74, 90.37, 89.71 and $86.25 \%$, respectively. Whereas, the formulation made with lignin PC 1307 and biochar with $\mathrm{NaHCO}_{3}$ gave the significant mortalities tended to be intermediate 78.89 and $63.52 \%$, respectively. However, the formulations containing chitosan, chitosan with $\mathrm{NaOH}(0.1 \mathrm{M})$, pyrolysis bio-oilaqoues phase, and pyrolysis biooilorganic phase gave the lowest significant mortalities as $27.78,12.21,11.12$ and $6.70 \%$, respectively. 
The products of spray-dried containing diatomaceous earth (DE), dextrin, skim milk powder (SKM) and biochar (with buffer adjusted $\mathrm{pH}$ at 6.8) were greater recovery percentages of $91.61,81.85,78.34$ and $74.62 \%$ than other tested compounds. On the other hand, water activity $\left(\mathrm{a}_{\mathrm{w}}\right)$ of the viral formulated samples was measured at $25{ }^{\circ} \mathrm{C}$ with an electronic meter and ranged from 0.013 to 0.307 in equilibrium with $1.3-30.7 \%$ relative humidity (Table 3).

Table 3. Recovery, water activity $\left(a_{w}\right)$ of the spray-dried formulation ingredients made with baculovirus AgipMNPV and mortality percentage (mean $\pm \mathrm{se}$ ) of Agrotis ipsilon exposed to the formulated virus.

\begin{tabular}{|c|c|c|c|c|c|}
\hline \multirow[t]{3}{*}{ No. } & \multirow{3}{*}{ Ingrdeients } & \multicolumn{3}{|c|}{ Spray-dried formulation ingrdeients } & \multirow{3}{*}{$\begin{array}{c}\text { Mortality } \\
\text { Percentage } \\
(\text { mean } \pm \mathrm{se})^{*}\end{array}$} \\
\hline & & \multicolumn{2}{|c|}{ Recovery } & \multirow{2}{*}{$\begin{array}{c}\text { Water activity } \\
\left(\mathrm{a}_{\pi}\right) \\
\text { at } 25^{\circ} \mathrm{C}\end{array}$} & \\
\hline & & weight $(g)$ & $\%$ & & \\
\hline 1 & Wheat germ & 2.06 & 32.96 & 0.248 & $92.08 \pm 4.89$ \\
\hline 2 & Talc & 4.38 & 70.08 & 0.284 & $100.00 \pm 0.00$ \\
\hline 3 & Silica gel & 4.04 & 64.64 & 0.252 & $100.00=0.00$ \\
\hline 4 & Calcium carbonate & 3.79 & 60.64 & 0.307 & $100.00=0.00$ \\
\hline 5 & Corn flour & 3.38 & 54.08 & 0.263 & $100.00=0.00$ \\
\hline 6 & Calcium cassinate & 2.25 & 36.00 & 0.216 & $100.00=0.00$ \\
\hline 7 & Aluminium Potassium sulphate & 1.22 & 19.52 & 0.241 & $90.37 \pm 3.09$ \\
\hline 8 & Magnsium Chloride & 2.22 & 35.52 & 0.227 & $90.74 \pm 8.54$ \\
\hline 9 & Lignin PC 1307 & 3.49 & 55.84 & 0.256 & $78.89 \pm 7.64$ \\
\hline 10 & Blankphor & 1.73 & 26.62 & 0.162 & $89.73 \pm 4.69$ \\
\hline 11 & Date molasses & 1.73 & 27.66 & 0.170 & $91.25 \pm 9.07$ \\
\hline 12 & Biochar $(125 \mathrm{~mL})+200 \mathrm{~mL} \mathrm{NaHCO}$ & 16.79 & 74.62 & 0.250 & $63.52 \pm 7.92$ \\
\hline 13 & Chitosan $+50 \mathrm{~mL} \mathrm{NaOH}(0.1 M)$ & 2.10 & 70.00 & 0.24 & $12.21 \pm 2.89$ \\
\hline 14 & Bio-oil (pyrolvsis organic phase) & 0.17 & 2.72 & 0.013 & $6.70 \pm 3.63$ \\
\hline 15 & Bio-oil (pyrolysis aqueous phase) & 0.06 & 0.96 & 0.017 & $11.12 \pm 3.39$ \\
\hline 16 & Pregelatinized starch & 4.25 & 67.95 & 0.190 & $86.25 \pm 15.48$ \\
\hline 17 & Diatomaceous earth (DE) & 5.73 & 91.61 & 0.210 & $100.00=0.00$ \\
\hline 18 & Soy Screen & 2.78 & 44.44 & 0.230 & $100.00 \pm 0.00$ \\
\hline 19 & Dextrin & 5.12 & 81.85 & 0.210 & $100.00 \pm 0.00$ \\
\hline 20 & Skim milk powder (SKM) & 4.90 & 78.34 & 0.210 & $94.18 \pm 2.42$ \\
\hline 21 & Potassium cassinate & 3.05 & 48.76 & 0.290 & $93.75 \pm 2.89$ \\
\hline 22 & Chitosan & 1.50 & 66.67 & 0.290 & $27.78 \pm 13.23$ \\
\hline 23 & $\begin{array}{l}\text { Biochar }+20 \mathrm{~mL} \text { potassium phatlate } \\
0.05 \mathrm{M} \text {, huffer } 4.0\end{array}$ & 2.80 & 44.44 & 0.230 & $91.85 \pm 3.65$ \\
\hline
\end{tabular}

* Analysis of variance $(\mathrm{F})=120.72$; degree of freedom $(\mathrm{df})=22,206 ;$ Probability $(P)<0.0001$; critical value for comparison $=2.26$; and standard error for comparison $=6.2$.

The cutworm, A. ipsilon is a pest causing damage to a variety of plants. A recently discovered baculovirus has the potential to be developed as a microbial-based biological pesticide to provide targeted control of this insect pest. In an effort to develop this baculovirus as a biological pesticide, experiments were conducted to evaluate the insecticidal activity of different viral ingredient formulations against cutworm larvae.

Formulation ingredients that enhance the active ingredient such as sugar, starch, lignin, and flour provide more than one benefit to biological pesticides. It has been acted as a phagostimulant, facilitating adhesion of the virus to plants, it is thought to play a role in protecting the occlusion body when it dries on the crop, and improved field performance and storage stability of a baculovirus. These can be used as carriers or encapsulating agents to spray-dry the active ingredients (Tamez-Guerra et al. 2002). 


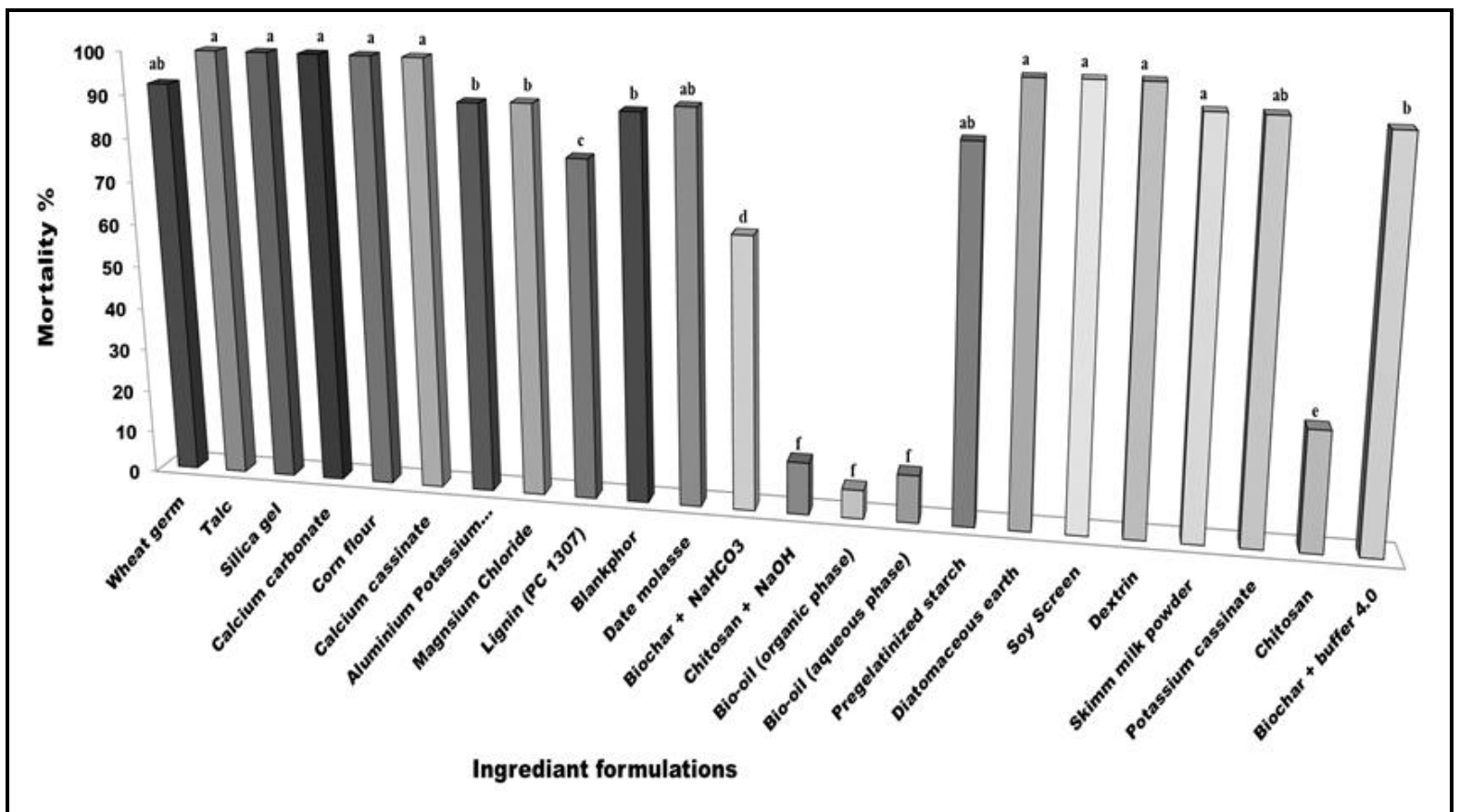

Fig. 1. Percentage mortality of different formulation ingredients for baculovirus AgipMNPV against cut worm, Agrotis ipsilon

Means followed by the same letter are not significantly different (LSD) $(\mathrm{F}=120.72 ; \mathrm{df}=22,206 ; P<0.0001$; critical value for comparison $=2.26$; standard error for comparison $=6.2$ ).

Various compounds have been reported as a potential adjuvant for inclusion in baculovirus formulations to overcome some of the inherent biological limitations, act as feeding stimulants and provide UV protection. Among these compounds optical brighteners, chitinase, boric acid, gums, sugar, pregelatinized flour, lignin, starch, talc, ground maize cob, maize oil and botanical extracts have received some interest as an attempt to enhance the efficacy of baculoviruses, protect from environmental factors that may inactivate it; increased viral persistence, and by accelerating the development of the disease (Mascarin \& Delalibera 2012; and Behle et al., 2006).

Water activity is defined as the ratio of the water vapor pressure of a material to the vapor pressure of pure water at the same temperature (Robertson, 2006). It is a straightforward measure of water available for chemical and biological reactions and, therefore, a meaningful parameter in studies with dehydrated microorganisms. The unformulated virus suspension contained a higher microbial load throughout the accelerated storage period than the formulated samples. Although the formulated samples may contain more nutrients for contaminating bacteria, the free water content in the unformulated virus suspension may be higher, whereas the formulated suspensions would have contained molecularly bound water (Burges and Jones, 1998). Microorganisms rely on water activity of above 0.6 in their environment to reproduce (Esse et al., 2004). The water activity of the suspensions was expected to be lower in the formulated suspensions and this could be the reason for the higher microbial load in the unformulated suspension. These studies identified key storage conditions that improved storage stability and will facilitate the commercial development of viral-based bioinsecticides. The production of baculovirus OBs in sufficient quantity for commercialization is often labor-intensive. Better control possibly could be sustainably improved by selecting for AgipMNPV strains having higher virulence, or by formulating the virus with synergists or performance-enhancing adjuvants. Since largescale commercial production of baculovirus biocontrol agents is mainly require large insect rearing facilities as well as techniques for infection of larvae, OB purification, and 
formulation. Behle (2017) reported that the development of this baculovirus is considering as an additional tool for the integrated control of the cutworm. However, other challenges of the development of baculovirus biopesticides concern the production, safety, and stability of baculoviruses in the field. The present findings open up new issues on the compatibility of these ingredients so that a viable viral formulation can be developed with enhanced efficacy.

\section{Conclusion}

As a result, the differences in insecticidal activities from the present work showed that talc, silica, calcium carbonate, cornflour, calcium cassinate, diatomaceous earth, soy screen, dextrin. wheat germ, date molassese plus wheat germ, pregelatinized starch, potassium cassinate, potasium aluminium, blankphor, magnsium chloride, and biochar (with buffer 4.0) formulations trended to provide greater mortality of exposed insects compared with other formulations and can be used to enhancing the production baculovirus formulation biopesticide for cutworm, A. ipsilon control.

\section{Acknowledgements}

This cooperative research was made possible by Agricultural Research Center (ARC), Plant Protection Research Institute (PPRI), Egypt and United States Department of Agriculture (USDA), Agricultural Research Service (ARS), National Center for Agricultural Utilization Research (NCAUR), USA.

Disclaimer: Mention of trade names or commercial products in this publication is solely for the purpose of providing specific information.

Funding:There are no funding sources for this manuscript.

Ethics approval and consent to participate:This article does not contain any studies with human participants or animals.

\section{REFERENCES}

Arthurs, S. P., Lacey, L. A., (2004) Field evaluation of commercial formulations of the codling moth granulovirus: Persistence of activity and success of seasonal applications against natural infestations of Codling Moth in Pacific Northwest apple orchards. Biological Control, 31: 388-397.

Behle, R.W. (2017) In vivo production of Agrotis ipsilon nucleopolyhedrovirus for quantity and quality. Journal of Economic Entomology. 111(1):101-107. doi: 10.1093/jee/tox315.

Behle, R.W., Compton, D.L., Kenar, J.A., Shapiro-Ilan, D.I. (2011) Improving formulations for biopesticides: enhanced UV protection for beneficial microbes. ASTM Special Tech. Pub. 1527 STP: 137-157.

Behle, R.W., Tamez-Guerra, P., McGuire,M.R. (2006) Evaluating conditions for producing spray-dried formulations of Anagrapha falcifera nucleopolyhedroviruses (AfMNPV). Biocontrol Sci. Technol. 16, 941-952.

Binning, R. R., Coats, J., Kong, X. \& Hellmich, R. L. (2015) Susceptibility to Bt proteins is not required for Agrotis ipsilon aversion to Bt maize. Pest Manag Sci 71, 601-606.

BioStat (2009) A software program for excel developed by AnalystSoft Inc. WALNUT, CA 91789. http://www.analystsoft.com

Brosi, B.A.J. B. and Potter, A. D. (2010) Evaluating a Naturally Occurring Baculovirus for Extended Biological Control of the Cutworm (Lepidoptera: Noctuidae) in Golf Course Habitats. Department of Entomology, S-225 Agriculture Science Bldg. N., University of Kentucky, Lexington, KY 40546-0091. J. Econ. Entomol., 103(5): 1555ذ1563 (2010); DOI: 10.1603/EC10171

Boughton, A.J., Lewis, L.C., Bonning, B.C. (2001) Potential of Agrotis ipsilon nucleopolyhedrovirus for suppression of the cutworm (Lepidoptera: Noctuidae) and 
Effect of an optical brightener on Virus Efficacy. J. Econ. Entomol. 94(5): 10451052.

Bourner, T.C., Cory, J.S. (2004) Host range of an NPV and a GV isolated from the common cutworm, Agrotis segetum: Pathogenicity within the cutworm complex. Biol. Control 31, 372-379.

Burges, H. D., Jones, K. A. (1998) Formulation of bacteria, viruses and protozoa to control insects. In: H. D. Burges, (Ed.), Formulation of Microbial Biopesticides. Kluwer Academic Publishers, London, pp. 33-127.

Cory, J. S. and Myers, J. H. (2003). The ecology and evolution of insect baculoviruses. Annu. Rev. Ecol. Evol. Syst. 34: 239-272.

Erlandson, M. (2008). Insect pest control by viruses. Encycl. Virol. 3: 125-133.

Esse, R., Saari, A., USA, H. I. (2004) Shelf-life and moisture management. In: R. Steele, (Ed.), Understanding and measuring the shelf-life of food. Woodhead Publishing, Cambridge England, pp. 24-41.

Harrison, R.L. (2013). Concentration- and time-response characteristics of plaque isolates of Agrotis ipsilon multiple nucleopolyhedrovirus derived from a field isolate. J. Invertebr. Pathol. 112, 159-161.

Harrison, R.L. (2009). Genomic sequence analysis of the Illinois strain of the Agrotis ipsilon multiple nucleopolyhedrovirus. Virus Genes 38, 155-170.

Herniou, E.A., Arif, B.M., Becnel, J.J., Blissard, G.W., Bonning, B.C., Harrison, R.L., Jehle, J.A., Theilmann, D.A., Vlak, J.M. (2011) Baculoviridae, in: King, A.M.Q., Adams, M.J., Carstens, E.B., Carstens, E.J., Lefkowitz, E.J. (Eds.), Virus Taxonomy. Elsevier, Oxford, pp. 163-174.

Hughes, P. R., N. A. M. van Beek, \& H. A. Wood. (1986). A modified droplet feeding method for rapid assay of Bacillus thuringiensis and baculoviruses in noctuid larvae. J. Invertebr. Pathol. 48:187-192.

Ikeda, M., Hamajima, R., Kobayashi, M., 2015). Baculoviruses: diversity, evolution and manipulation of insects. Entomological Science, 18, 1-20.

Jones, K., \& Burges, H. (1997) Product Stability: From experimental preparation to commercial reality. BCPC Symposium Proceedings. 68, 163-171.

Kabaluk, J.T., Svircev, A.M., Goettel, M.S., Woo, S.G. (2010) The use and regulation of microbial pesticides in representative jurisdictions worldwide. IOBC Glob. 99.

Lasa, R., Williams, T., Caballero, P. (2009). The attractiveness of phagostimulant formulations of a nucleopolyhedrovirus-based insecticide depends on prior insect diet. J. Pest. Sci. 82: 247-50.

Liu, Y. Q., Fu, X. W., Feng, H. Q., Liu, Z. F. \& Wu, K. M. (2015). Trans-regional migration of Agrotis ipsilon (Lepidoptera: Noctuidae) in North-East Asia. Ann. Entomol. Soc. Am. 108, 519-527.

Mascarin G.M., Delalibera, I. Jr. (2012) Insecticidal activity of the granulosis virus in combination with neem products and talc powder against the potato tuberworm Phthorimaea operculella (Zeller) (Lepidoptera: Gelechiidae). Neotrop Entomol (2012) 41:223-231. DOI 10.1007/s13744-012-0044-X.

Prater, C. A., Redmond, C. T., Barney, W., Bonning, B. C., Potter, A. D. (2006). Microbial control of cutworm (Lepidoptera: Noctuidae) in turfgrass using Agrotis ipsilon multiple nucleopolyhedrovirus. J. Econ. Entomol. 99(4): 1129-1137.

Robertson, G.L. (2006). Food Packaging - Principles and Practice. Second edition, CRC Press, Boca Raton, FL, USA. 314-319.

Seaman, D. (1990) Trends in the formulation of pesticides - an overview. Pesticide Science. 29, 437-449. 
Szewczyk, B., Rabalski, L., Krol, E., Sihler, W., Souza, M.L. (2009) Baculovirus biopesticides - a safe alternative to chemical protection of plants. J. Biopestic. 2, 209216.

Tamez-Guerra, P., McGuire, M. R., Behle, R. W., Shasha, B. S., Pingel, R. L. (2002). Storage stability of Anagrapha falcifera nucleopolyhedrovirus in spray-dried formulations. Journal of Invertebrate Pathology. 79, 7-16.

Wang D, Zhang W, Hao X, Zhou D (2013). Transport of biochar particles in saturated granular media: Effects of pyrolysis temperature and particle size. Environmental Science Technology, 47 (2): 821-828.

\section{ARABIC SUMMARY}

\section{AgipMNPV تحسين فاعلية بعض مستحضرات الرش الفيروسية المجفة

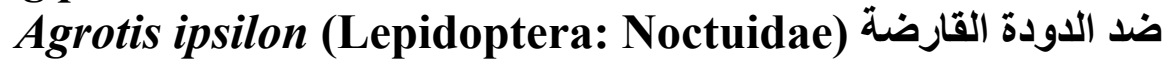

عاطف محمود محمد سيد' - روبرث بيهال' - غادة نبيل عبد الرحمن المصري'

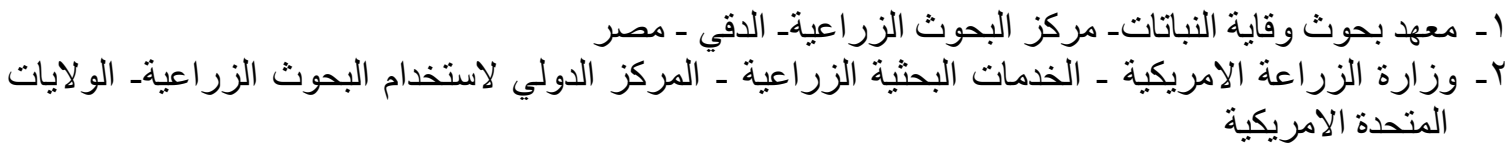

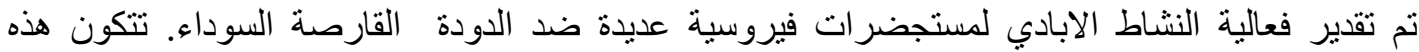

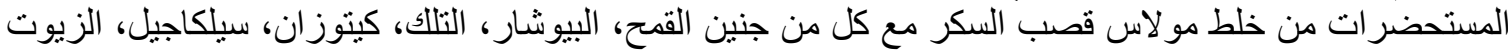

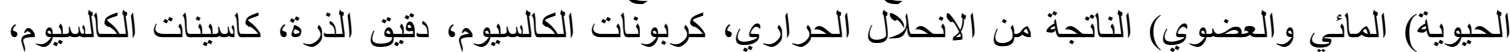

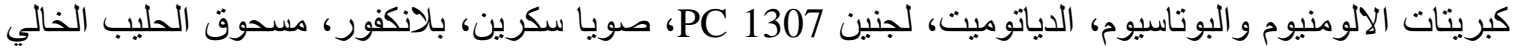

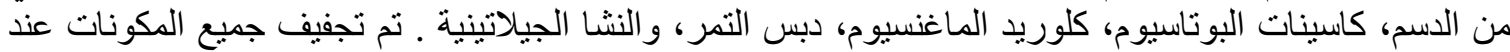

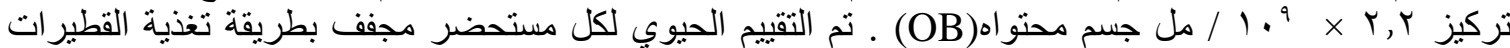

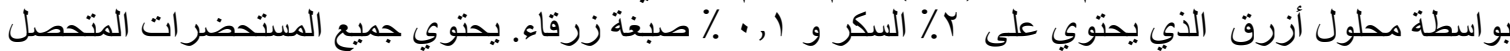

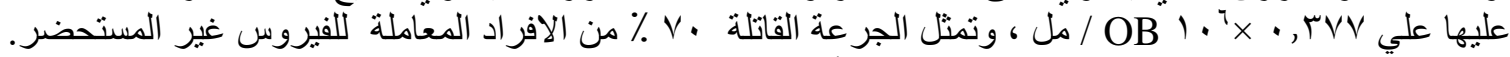

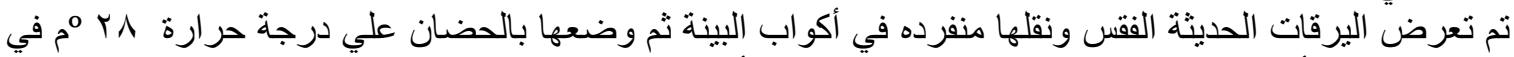

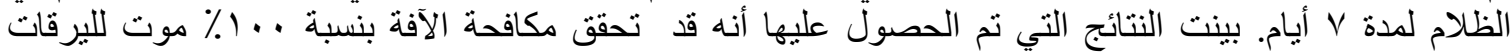

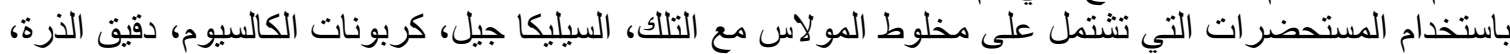

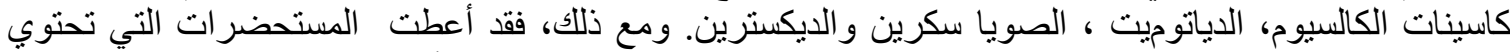

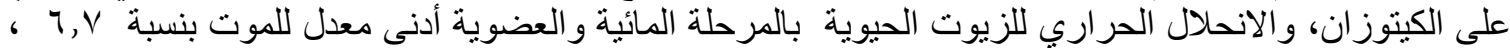

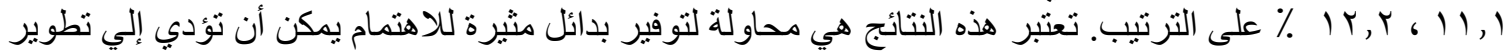

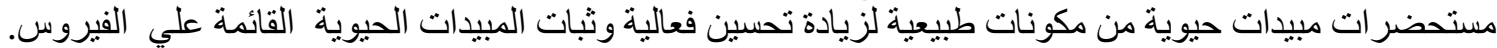

